\title{
Correction to: Exploiting context-dependent preferences to protect borrowers
}

\author{
Linda Dezső ${ }^{1}$ (B) Barna Bakó ${ }^{2} \cdot$ Gábor Neszveda $^{3}$
}

Published online: 6 December 2021

(c) The Author(s) 2021

\section{Correction to: Journal of Financial Services Marketing https://doi.org/10.1057/s41264-021-00124-x}

The original version of this article unfortunately contained a mistake. The affiliation details of Barna Bakó and Gábor Neszveda were incorrect.

The correct affiliations are:

Barna Bakó

Institute of Economics, Corvinus University of Budapest, Fővám tér 8, 1093-Budapest, Hungary

Gábor Neszveda

John von Neumann University, Izsáki út 10, 6000-Kecskemét, Hungary

Open Access This article is licensed under a Creative Commons Attribution 4.0 International License, which permits use, sharing, adaptation, distribution and reproduction in any medium or format, as long as you give appropriate credit to the original author(s) and the source, provide a link to the Creative Commons licence, and indicate if changes were made. The images or other third party material in this article are included in the article's Creative Commons licence, unless indicated otherwise in a credit line to the material. If material is not included in the article's Creative Commons licence and your intended use is not permitted by statutory regulation or exceeds the permitted use, you will need to obtain permission directly from the copyright holder. To view a copy of this licence, visit http://creativecommons.org/licenses/by/4.0/.

The original article can be found online at https://doi.org/10.1057/ s41264-021-00124-x.

Linda Dezső

linda.dezsoe@univie.ac.at

1 Vienna Center for Experimental Economics, University of Vienna, Oskar Morgenstern Platz 1, 5.313, 1090 Vienna, Austria

2 Institute of Economics, Corvinus University of Budapest, Fővám tér 8, 1093 Budapest, Hungary

3 John von Neumann University, Izsáki út 10, 6000 Kecskemét, Hungary 
Publisher's Note Springer Nature remains neutral with regard to jurisdictional claims in published maps and institutional affiliations. 